\title{
The Use of Magic in Alpha Zone-Based Indonesian Language Learning Apperception
}

\author{
Zulfa Fahmy ${ }^{1}$, Titi Wuryani² \\ \{zulfafahmy@mail.unnes.ac.id ${ }^{1}$,wuryani.titi@gmail.com\} \\ ${ }^{1}$ Universitas Negeri Semarang, Semarang, Indonesia \\ ${ }^{2}$ MA NU 06 Cepiring, Kendal, Indonesia
}

\begin{abstract}
Every day, students are burdened with fairly dense learning. The average student time allocation when they are studying at school is not less than 8 hours per day and many subjects are quite a lot. If the teacher does not implement the learning strategy, students will get bored or tired. Therefore, the learning process must begin excitingly. Apperception becomes an important part of learning, especially in an Indonesian Language subject. The use of the Alpha Zone in Indonesian Language learning can be an alternative solution for the problem. The Alpha Zone Strategy is used to condition the brains of students so that they will be ready to receive learning. Through this strategy, the material delivered by the teacher will be more readily understood by students. The conditioning of students' brains to the Alpha Zone can be accomplished in several ways. In this article, the conditioning uses magic as its media.
\end{abstract}

Keywords: alpha zone, apperception, learning

\section{INTRODUCTION}

The revision of the current curriculum prioritizes creativity for students. Especially in facing the industrial era 4.0, creativity is one of the primary skills that must be mastered by everyone. The creative element has a portion in student assessment. Students who relatively even tend to be "naughty" are facilitated by the teacher by using each teacher way. Therefore, teachers do not only look at measurable values, but also non-test benefits that can be a potential for student development.

Creative students also come from creative teachers. The teacher's creativity must be reflected in the way of how teachers manage the learning scenario. It is known that in the core competencies and basic competencies of the 2013 curriculum, the material is presented repeatedly until students can master maximally. If the teacher's creativity does not accompany this condition in delivering the learning, it is no wonder if students will get bored with the teacher, the subjects, and even they will lazy to do the assignment. Therefore, teachers are required always to be creative.

Apperception is the main gate to enter the creative world of students. Teachers who start lessons with lectures and ask assignments are certainly very boring. While teachers who start lessons with something creative, namely singing, it will encourage students to study harder. 
In learning theory, the most suitable brain condition for inserting subject material into a student's brain is when a student is in the alpha zone. In this zone, the student's brain is ready to accept any material provided by the teacher.

Khuluqiyah [1] used alpha zone-based apperception in physics learning. The result is students who applied the Brain Gym Alpha Zone strategy obtained better learning achievement than students who did not apply the Alpha Zone strategy. Besides Khuluqiyah, Fatma [2] conducted research by using Fun Story and music to condition students before starting the lesson. The result is that students' motivation in participating the learning in class was better than students who only got conventional learning. Based on some of these studies, it can be concluded that the use of the Alpha Zone for apperception of learning is very influential on the quality of learning produced.

Entering the alpha zone can be implemented in various ways, including music, joke, and ice breaking. Music, joke, and ice-breaking can lead students to enter the alpha zone. Music for students is very diverse, very subjective. It means that not all music played will be liked by students. A joke is not easy to be delivered by all teachers. If the teacher does not master the joke material, students will find the teacher is not funny, tends to be forced. Therefore, icebreaking becomes the best way for anyone if someone wants to enter the alpha zone.

Ice-breaking is very various, namely brain games, finger games, even guessing. Magic is one of the effective alternatives for ice-breaking to enter the alpha zone. People like something that makes them curious. Magic presents it as a whole. If the teacher can combine it with learning, it is undoubtedly that students will be fully controlled and their thinking skills go well. As research by Diana [3] who researched the Use of Magic Games to Improve the Understanding of the Group A Child Numbers Concept in Wisnuwardhana Wonosari Kindergarten, Malang Regency. Diana's research results show that magic media can improve student learning achievement. Not only Diana, but Wahyudi [4] also uses magic media to solve physics problems. Wahyudi's research results show that the effectiveness of the Teams Game Tournament model increases when using magic media. The same thing was conducted by Kamaludin [5]. However, Kamaludin researched about the use of magic for propaganda. Magic is used in the chosen method of preaching for mosque youth.

The learning that has been conducted by teachers tends to be monotonous. Students feel bored at school, especially if the teacher does not implement interesting learning. Here is some identification of problems related to learning in class. First, teachers are required to teach creatively, but they are not encouraged to be creative. Second, the teacher does not recognize the condition of students' brain. Third, students who are not enthusiastic in learning will hinder them from understanding knowledge. Fourth, the teacher is not aware of the function of learning apperception.

The identification of the problem is a small portion of the problems that occur in the learning process. Based on the identification of the problem, the problem formulation in this activity is (1) how to train the teacher to be able to understand the brain waves of students, and (2) how to train teachers to be able to use Alpha-based apperception in Indonesian language learning.

To encourage teacher awareness of the function of apperception is to provide knowledge to teachers about the level of the brain zone. The situation that occurs is the teacher only considers apperception as limited to asking questions or linking previous learning. This is completely wrong because apperception is an attempt by the teacher to condition students ready to learn. Perception is a conscious observation (appreciation) of everything in his soul (self), which is the basis of comparison and the basis for receiving new ideas (KBBI (6). New ideas are material that will be taught by the teacher; Apperception is not what teachers do. 
Apperception is a way to understand themselves to be ready to learn, but sometimes students find it challenging to condition themselves, so teachers need to create such conditions. Therefore, apperception is often interpreted as an act of classroom conditioning.

While Chatib [6] revealed that apperception is the process of asking for teaching rights from students, students owned the right to teach, and the teacher must ask him so he can teach. If students are willing to give the teaching right to a teacher, the teacher will definitely be accepted by their students when the learning process occurs. The essential thing to know is that teaching rights must be taken over by the teacher.

One of the ways to condition students so that they are ready to learn is by using the alpha zone apperception. This apperception relies on teachers' ability and creativity to do anything to prepare the mental condition of students so that they can ready to learn.

One of its ways is using magic. Magic as an art form has an extraordinary power to increase students' curiosity about whatever they see/ feel. So, the combination of alpha zones, apperception, and magic produces a formula that is sufficiently responsible for preparing the mental condition of students that ready to learn.

Based on these opinions, it can be concluded that apperception is the process of taking over the teaching rights of students in a special way that is carried out by the teacher so that students are consciously in a condition of ready to learn.

Chatib [6] said that the alpha zone is actually one of the brain waves. During this time, neurology has only been able to define four brain waves that record human activity in a day. One of them is Alpha Waves $(7-13 \mathrm{~Hz})$. Alpha condition is the most illuminating (brilliant) stage of a person's brain's creative process. This alpha condition is stated to be the best condition for learning because nerve cells are in harmony or balance. It is when a person's nerve cells fire electrical impulses and also rest simultaneously so that a balance arises and it is resulting in a person's relaxation conditions. At this time, a person is also stated to be in a state of transition between conscious and unconscious. It is caused the neural pathways are efficient so that the condition is believed by many experts to be the right condition for making suggestions, including teaching, and learning.

Four ways can bring us into alpha condition, namely ice-breaking, fun story, music, and brain gym. These four ways are usually used by Subject Teachers to their students, while students themselves can use this trick to be able to study at home effectively. One of them is listening to music while reading, writing (studying).

\section{RESULT AND DISCUSSION}

Activities conducted to train teachers in the use of the Alpha Zone apperception strategy first is to understand them about the condition of the Alpha Zone. The condition of students when entering the Alfa Zone is in waves 7-13 Hz. However, this wave indeed cannot be detected easily by the teacher. Therefore teachers must know the indicators of students who have entered the Alpha Zone. It will be explained in the following paragraphs.

\section{Students look comfortable and happy}

The comfortable feeling is the key to every learning. The comfortable feeling will be very detected easily when students dare to respond, look at the teacher's face, and so forth. In addition, a happy atmosphere is also a characteristic of students who have entered the alpha zone. A smile on their face can detect student happiness. 


\section{Students can pay attention to focus condition}

After the happy feeling appears, the next indicator is a focus. Students will always focus on the teacher; both concentrate on listening and concentrate on seeing. The simple features when the student in-focus condition is their gaze all fixed on the teacher or something that is showed by the teacher.

\section{Respond to questions or actions}

The next feature is responding. Students who have entered the alpha zone will react quickly to the things conducted by the teacher. This response can be in the form of verbal replies and action responses. The response that appears is the response expected by the teacher. It means that the response is following the flow of apperception and the learning context.

After knowing the alpha zone indicator in students, the teacher is trained to be able to codify students in the alpha zone. At this stage, researchers used the modelling technique. Modelling technique was used so that teachers understand quickly and can practice what they will learn. Furthermore, apperception training was conducted to teach teachers to play magic. It is explained in the following paragraph.

\section{Prediction Card}

The teacher can predict something the student chose. The predictions are always right.

Things that need to be prepared are (1) prepare two items (it can be borrowed from students),

(2) prepare predictions with the statement written like "I can ... You can .......". After that, follow the following steps.

a. Tell students that you can predict something that will happen.

b. Show the paper contains a choice of material that will be used as learning material (for example "Writing Poetry and Writing Short Stories."

c. Choose one student who will play with you.

d. Write your prediction on a paper, "I get Poetry, You get Short Story". Make sure no students see your predictions.

e. Fold the paper and show to students that you have made a prediction.

f. Ask the student who was chosen to choose one of the two objects prepared earlier (pencilruler)

g. This seventh step is the most decisive step for your magic success. If the student chooses Poetry, then give the prediction paper to the student and tell him to read it aloud. But if the student chooses the short story, then open the prediction paper and then read it in front of the other students. The point is you have to adjust your prediction to the student's choice. This is a normal trick and can be implemented at any time. There are a few tips for this trick, that is, when your students are aware of how the trick works, you can dodge "it is magic". In addition, the teacher must be good at linking learning to be delivered with the selected object.

After the teacher observes the modelling and explanation of the trick, they are asked to imitate and modify the technique. The results obtained are the teacher can use the technique correctly and felt fun. The statement is explained in the following paragraph. 


\section{Modification}

The first modification is conducted by increasing the number of student object choices. The teacher uses envelope and paper media to be used as the chosen object. The first envelope is filled by writing material to be delivered, for example, "News Text Structure", while funny words filled the other two envelopes, for instance, "Tomorrow is free!" And "Treated for eating!".

The steps taken by the teacher are as follows. First, show that the teacher has three envelopes contains today's lesson material. Then, show a prediction envelope. Then, ask one of the students to come forward and choose an envelope. When this happens, put the envelope that contains the subject material in the middle order. Students will tend to select the envelope in the middle location.

\section{Evaluation}

After the activities are carried out, the next step is to conduct an evaluation. Evaluation is done by interviewing the difficulties experienced during the activity. Some things that can be obtained from the evaluation are as follows. First, the teacher feels nervous when doing magic. It is because they are not used to doing this. They are still afraid of failing to do the trick. Second, the teacher is not good at using the right diction to instruct students so that the trick can run. That problem can be overcome by making a straightforward narrative on a piece of paper. Then the teacher memorizes it. Third, more apperception modification is needed by using magic because the nature of magic is not good if it is watched twice. Moreover, with a sufficient number of teaching hours, teachers must be able to modify more varied and not be boring.

\section{CONCLUSION}

Based on these explanations, it can be concluded that apperception by using magic helps teachers to condition students into the Alpha Zone. It makes teachers feel easier to deliver learning in the class.

\section{REFERENCE}

[1] K. Khuluqiyah, "Pengaruh Penerapan Zona Alfa dengan Kegiatan Brain Gym Terhadap Hasil Belajar Siswa Pada Materi Alat-Alat Optik di Kelas VIII SMP Islam Krembung Sidoarjo," Inov. Pendidik. Fis., vol. 1, no. 1, 2012.

[2] A. N. Fatma, "Pengaruh Pengkondisian Gelombang Otak Zona Alfa pada Apersepsi Pembelajaran Terhadap Motivasi Belajar Biologi Siswa Kelas XI IPA MAN 3 Makassar.” UIN Alauddin Makassar, 2016.

[3] K. DIANA, "Pemanfaatan Permainan Sulap untuk Meningkatkan PemahamanKonsep Bilangan Anak Kelompok A di TK Wisnuwardhana Wonosari Kabupaten Malang," SKRIPSI Jur. Kependidikan Sekol. Dasar Prasekolah-Fakultas Ilmu Pendidik. UM, 2016.

[4] D. Wahyudi, "EFEKTIFITAS MODEL TEAMS GAME TOURNAMENT (TGT) DENGAN MEDIA SULAP UNTUK MENYELESAIKAN SOAL FISIKA KELAS VII SMP NEGERI 1 KARIMUNNJAWA," Indones. J. Curric. Educ. Technol. Stud., vol. 2, no. 2, pp. 64-69, 2014.

[5] K. Kamaludin, "Dakwah melalui permainan sulap di kalangan remaja: analisis 
deskriptif dakwah Mochammad Syafril di remaja Masjid Al-Istiqomah Kelurahan Melong Kecamatan Cimahi Selatan Kota Cimahi.” UIN Sunan gunung Djati Bandung, 2018.

[6] M. Chatib, "Gurunya manusia menjadi semua anak istimewa dan semua anak juara," Jakarta PT. Mizan Pustaka, 2011. 